\title{
The role of blowing snow in the activation of bromine over first-year Antarctic sea ice
}

\author{
R. M. Lieb-Lappen and R. W. Obbard \\ 14 Engineering Drive, Thayer School of Engineering, Dartmouth College, Hanover, NH, USA \\ Correspondence to: R. M. Lieb-Lappen (ross.lieb-lappen@dartmouth.edu)
}

Received: 06 March 2015 - Published in Atmos. Chem. Phys. Discuss.: 22 April 2015

Revised: 18 June 2015 - Accepted: 30 June 2015 - Published: 13 July 2015

\begin{abstract}
It is well known that during polar springtime halide sea salt ions, in particular $\mathrm{Br}^{-}$, are photochemically activated into reactive halogen species (e.g., $\mathrm{Br}$ and $\mathrm{BrO}$ ), where they break down tropospheric ozone. This research investigated the role of blowing snow in transporting salts from the sea ice/snow surface into reactive bromine species in the air. At two different locations over first-year ice in the Ross Sea, Antarctica, collection baskets captured blowing snow at different heights. In addition, sea ice cores and surface snow samples were collected throughout the month-long campaign. Over this time, sea ice and surface snow $\mathrm{Br}^{-} / \mathrm{Cl}^{-}$ mass ratios remained constant and equivalent to seawater, and only in lofted snow did bromide become depleted relative to chloride. This suggests that replenishment of bromide in the snowpack occurs faster than bromine activation in mid-strength wind conditions (approximately $10 \mathrm{~m} \mathrm{~s}^{-1}$ ) or that blowing snow represents only a small portion of the surface snowpack. Additionally, lofted snow was found to be depleted in sulfate and enriched in nitrate relative to surface snow.
\end{abstract}

\section{Introduction}

The polar springtime is a season of change, most notably in temperature, sea ice coverage, and weather, but it also signals the onset of many photochemically driven atmospheric chemical reactions, such as tropospheric ozone depletion events (ODEs) (e.g., Barrie et al., 1988). Boundary layer ozone in polar regions has been observed to fall dramatically periodically in the spring in both the Arctic (Barrie et al., 1988) and Antarctic (Kreher et al., 1997; Wessel et al., 1998). These tropospheric ODEs are initiated by in- creased concentrations of reactive bromine gases $(\mathrm{BrO}$ and $\mathrm{Br}$ ) resulting in a catalytic removal of ozone (Fan and Jacob, 1992; McConnell et al., 1992; Frießet al., 2004); however the mechanism by which $\mathrm{Br}$ enters the atmosphere is not well understood (Abbatt et al., 2012). The heterogeneous reaction producing bromine gas and hypothesized to explain the "bromine explosion" is given by Fan and Jacob (1992):

$\mathrm{HOBr}+\mathrm{Br}^{-}+\mathrm{H}^{+} \rightarrow \mathrm{Br}_{2}+\mathrm{H}_{2} \mathrm{O}$.

Proposed surfaces on which this reaction may occur have included sea spray Sander et al. (2003), frost flowers (Rankin et al., 2000; Kaleschke et al., 2004), surface snow (Simpson et al., 2005), aerosols (Vogt et al., 1996; Frießet al., 2004), and blowing snow (Yang et al., 2008).

Although some bromide may arrive via sea spray produced aerosol (Sander et al., 2003), this mechanism is relatively less efficient and does not produce aerosol with the observed sulfate depletion (Wagenbach et al., 1998). As seawater freezes, salt rejection leads to an increasingly saline brine (Thomas and Dieckmann, 2009). Specific salts precipitate out of solution when solubility limits are reached below $-2{ }^{\circ} \mathrm{C}$ (Light et al., 2003), producing brine with different ion ratios than those found in seawater. The brine is expelled to the ice/snow or ice/atmosphere surface, where it forms a fractionated surface skim and slush (Rankin et al., 2002). This reservoir of bromide and other sea salts can be incorporated into frost flowers by wicking, or into the snow lying on sea ice by upward migration through capillary forces (Perovich and Richter-Menge, 1994). It may be transported by the lofting of snow from sea ice with subsequent sublimation and return of the aerosol to the snowpack (Yang et al., 2008; Jones et al., 2009). However, the physical surface at which bromide activation occurs remains a subject of some debate. 
It has been shown that brine is wicked upward by frost flowers that form on fresh sea ice, yielding a highly saline surface with the aforementioned sulfate depletion, and that the dendritic nature of frost flowers magnifies the surface area available for atmospheric interactions (Rankin et al., 2002). However, studies have shown that frost flowers do not significantly increase the surface area available for heterogeneous reactions (Domine et al., 2005; Obbard et al., 2009) and that frost flowers are not easily broken and lofted (Obbard et al., 2009). Instead, they accumulate snow on their windward side in strong winds and when broken, fall where they are (Obbard et al., 2009). Laboratory studies of frost flowers have also shown that frost flowers are quite stable in winds up to $12 \mathrm{~ms}^{-1}$, and aerosol production is not observed under these conditions (Roscoe et al., 2011). Further, Simpson et al. (2005) and Obbard et al. (2009) found that frost flowers are not depleted in bromide relative to sodium and chloride, indicating they are not the immediate source of bromine-depleted snow nor the location of the heterogeneous reactions activating bromine. It has also been shown that first-year sea ice contact better correlates to increased $\mathrm{BrO}$ concentrations than does contact with potential frost flower regions (Simpson et al., 2007a).

In Simpson et al. (2005) however, the snowpack did have $\mathrm{Br}^{-} / \mathrm{Na}^{+}$ratio fluctuations by 2 orders of magnitude with bromide depletions of up to $90 \%$, suggesting bromine was released in the aerosol phase or in the snowpack itself. Sea salts can migrate upwards through the snowpack as high as $17 \mathrm{~cm}$, even in cold conditions where slush is not present (Massom et al., 2001; Domine et al., 2004). However, in thicker snowpacks, the surface snow is more readily acidified and influenced by atmospheric processes, and thus, more likely to play a role in halogen activation. Bromine activation is more efficient in acidic conditions and in environments with a higher $\mathrm{Br}^{-} / \mathrm{Cl}^{-}$ratio (Pratt et al., 2013). Pratt et al. (2013) further hypothesized that the snowpack interstitial air is the primary location for the heterogeneous reactions, with wind pumping providing a vehicle to release the bromine into the boundary layer.

Yang et al. (2008) proposed a fourth mechanism for bromine activation that involves the lofting of snow from sea ice with subsequent sublimation and either direct bromine release or return of the aerosol to the snowpack. In the model, lofted snow particles were allowed to sublimate to a particle size of $<10 \mu \mathrm{m}$, whereby the particles instantaneously released bromine or were potentially scoured by more blowing snow particles. Snow salinity was found to have a nonlinear relationship with bromine production, and the reaction rate varied with dry aerosol particle size. It was shown that $1.3 \mu \mathrm{m}$ particles yielded the most efficient release of bromine since the smaller aerosol could be lofted further and longer (Yang et al., 2008). Further work showed that snow in the sea ice zone may contain enough salt when lofted by wind to produce the necessary aerosol to explain the observed Antarctic ODEs (Yang et al., 2010). While it may be difficult for satu- rated snow lying on surface skim to become lofted, snow in the upper layers could wick up salts yet remain mobile, providing enormous capacity for transporting bromide into the boundary layer. Yang et al. (2008) provides the theoretical framework and model-based data for the physical measurements observed and presented in this manuscript.

ODEs have been found to occur at a range of wind speeds, something that has made agreement upon a mechanism difficult. Some have observed that ODEs require low winds, a stable boundary layer, and a relatively clear sky, or the movement of air masses from such regions (Simpson et al., 2007b). Using measurements and modeling, Albert et al. (2002) found rapid ozone depletion in the top $10 \mathrm{~cm}$ of the snowpack due to diffusion and ventilation in moderate winds. More recently, ODEs have been recorded during high winds $\left(>12 \mathrm{~m} \mathrm{~s}^{-1}\right)$, which increase the snow surface area exposed via blowing snow, and thus, the probability of contact between the gaseous and condensed phases required to initiate bromine release (Jones et al., 2009). During the 2009 OASIS campaign in Barrow, AK, high winds were observed to correspond with increased BrO concentrations (Frießet al., 2011). This was accompanied by decreased $\mathrm{HOBr}$, suggesting that blowing snow likely provided additional surfaces for heterogeneous HOBr loss (Liao et al., 2012). These high wind halogen activation events may have a more widespread role when considering the impact of ODEs on regional tropospheric chemistry (Jones et al., 2010). Additionally, higher winds may enhance the availability of radical bromine precursors in the snowpack, accelerating bromine activation (Toyota et al., 2011). On the contrary, others (e.g., Helmig et al., 2012; Halfacre et al., 2014) have found no correlation between ODEs and wind speed. However, the lack of low ozone observations at high wind speed may be a result of enhanced mixing (Helmig et al., 2012). Although the chemistry of snow has been well studied (Massom et al., 2001; Domine et al., 2004; Grannas et al., 2007), there has been no attempt until now at segregating snow capable of wind transport or snow actually blown by wind.

It is noted that both $\mathrm{Cl}_{2}$ and $\mathrm{BrCl}$ play a role in halide boundary layer chemistry and ODEs (Abbatt et al., 2012), but the focus of this work is on bromine because it is a far more efficient catalyst of ozone loss. As the main constituents of seawater, both chloride and sodium have been used as sea salt tracers, and thus chloride was used here to both determine snow and ice salinity and relative activity of other anions. Previous work has shown that sulfate is influenced both by mirabilite precipitation and atmospheric interactions, while nitrate is uncorrelated with sea salt and is deposited as a byproduct of other reactions (Krnavek et al., 2012).

\section{Methods}

Two field sites on first-year sea ice in the Ross Sea, Antarctica, were chosen, based upon prevailing wind direction, to 


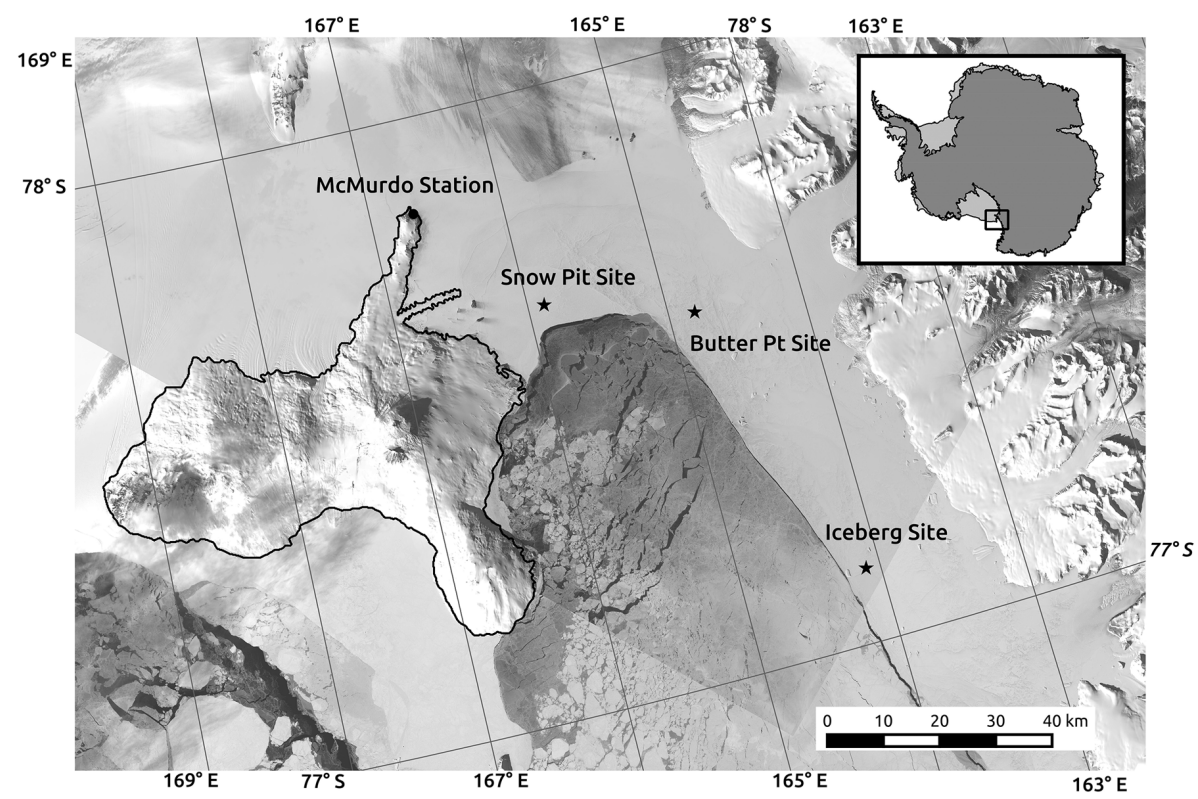

Figure 1. Map of the Ross Sea region showing the two field sites Butter Point and Iceberg. Basemap is Landsat image.

maximize contact of the blowing snow with the first-year sea ice. Their locations are shown in Fig. 1. Butter Point Site was located $6.5 \mathrm{~km}$ from the open ocean and $35 \mathrm{~km}$ north of the Ross Ice Shelf. Iceberg Site was located $55 \mathrm{~km}$ northwest of Butter Point, and since the ice edge located to the east follows the shore, the distance to open water here was also $5 \mathrm{~km}$. Iceberg Site was chosen based upon the presence of a $740 \mathrm{~m}$ long and $35 \mathrm{~m}$ high iceberg located $250 \mathrm{~m}$ to the west that would block winds sourced over land, maximizing blowing snow collection from over sea ice. At each site, a $5.5 \mathrm{~m}$ blowing snow collection tower was erected for the time period of 11 October-08 November 2012. Collection baskets made out of $150 \mu \mathrm{m}$ nylon monofilament mesh and $7^{\prime \prime}$ diameter by $14^{\prime \prime}$ long (Midwest Filter Corporation, Lake Forest, IL) were placed at four different heights: $0.3,2.0,3.0$, and $5.5 \mathrm{~m}$ above the snow surface.

The sites were visited approximately every other day, and collection baskets were switched even if no snow was collected. Baskets were triple rinsed with DI water between uses. Surface snow samples were collected each of the 12 days the sites were visited. In addition, 1.78 and $1.89 \mathrm{~m}$ ice cores were extracted from Butter Point and Iceberg sites, respectively. Snow samples and sea ice cores were transported at a constant temperature of $-20^{\circ} \mathrm{C}$ back to Thayer School of Engineering's Ice Research Laboratory at Dartmouth College and stored in $\mathrm{a}-33^{\circ} \mathrm{C}$ cold room.

Winds during the field campaign were generally mild, only surpassing $10 \mathrm{~m} \mathrm{~s}^{-1}$ on a few occasions. Site visits were not feasible during stormy weather, and much of the blowing snow captured during those periods sublimated in the baskets prior to collection as observed by a webcam. Thus, only on 25 October were blowing snow samples collected at both sites and all four heights. The collected snow was the result of approximately $10 \mathrm{~m} \mathrm{~s}^{-1}$ southerly winds on 24 October. Visibility at McMurdo station during this blowing snow event dropped below 0.5 miles for about $4 \mathrm{~h}$. Temperatures ranged from -20.5 to $-11.5^{\circ} \mathrm{C}$ with an average relative humidity of $69 \%$ on 24 October and -17.5 to $-13.5^{\circ} \mathrm{C}$ with an average relative humidity of $61 \%$ on 25 October. These temperatures were a couple of degrees warmer than the average for the rest of the field campaign.

All surface snow and blowing snow samples were melted into acid-rinsed HDPE vials, and diluted by a factor of 5 with DI water. Those samples falling outside of the calibration standard concentrations were further diluted to fall within the desired range. Each ice core was sub-sampled every $10 \mathrm{~cm}$, melted, and diluted by a factor of 50, except for the bottommost sample that was diluted by a factor of 100 . A $0.5 \mathrm{~mL}$ aliquot of each diluted snow and ice sample was then analyzed for anion concentrations.

Anion chromatography was completed using a Dionex600 IC system, equipped with a LC 25 chromatogram oven set at $30^{\circ} \mathrm{C}$, GD 50 gradient pump, CD 25 conductivity detector, AS15 anion column with a AG15 guard column, and an auto-sampler. A $38 \mathrm{mM} \mathrm{NaOH}$ eluent was used at a flow rate of $1.2 \mathrm{~mL} \mathrm{~min}^{-1}$ and the SRS current was set to $100 \mu \mathrm{A}$. Pressure in the column was $1600 \mathrm{psi}$ and the signal noise was approximately $0.003 \mu \mathrm{S}$. Peak analysis was performed using Chromeleon 6.8 software with a 5 point standard calibration curve. IC detection limits were 0.6, 0.1, 0.04, and $0.03 \mathrm{~g} \mathrm{~m}^{-3}$, yielding limits of quantification of $2,0.3,0.1$, and $0.1 \mathrm{~g} \mathrm{~m}^{-3}$ for chloride, sulfate, bromide, and nitrate, respectively. 

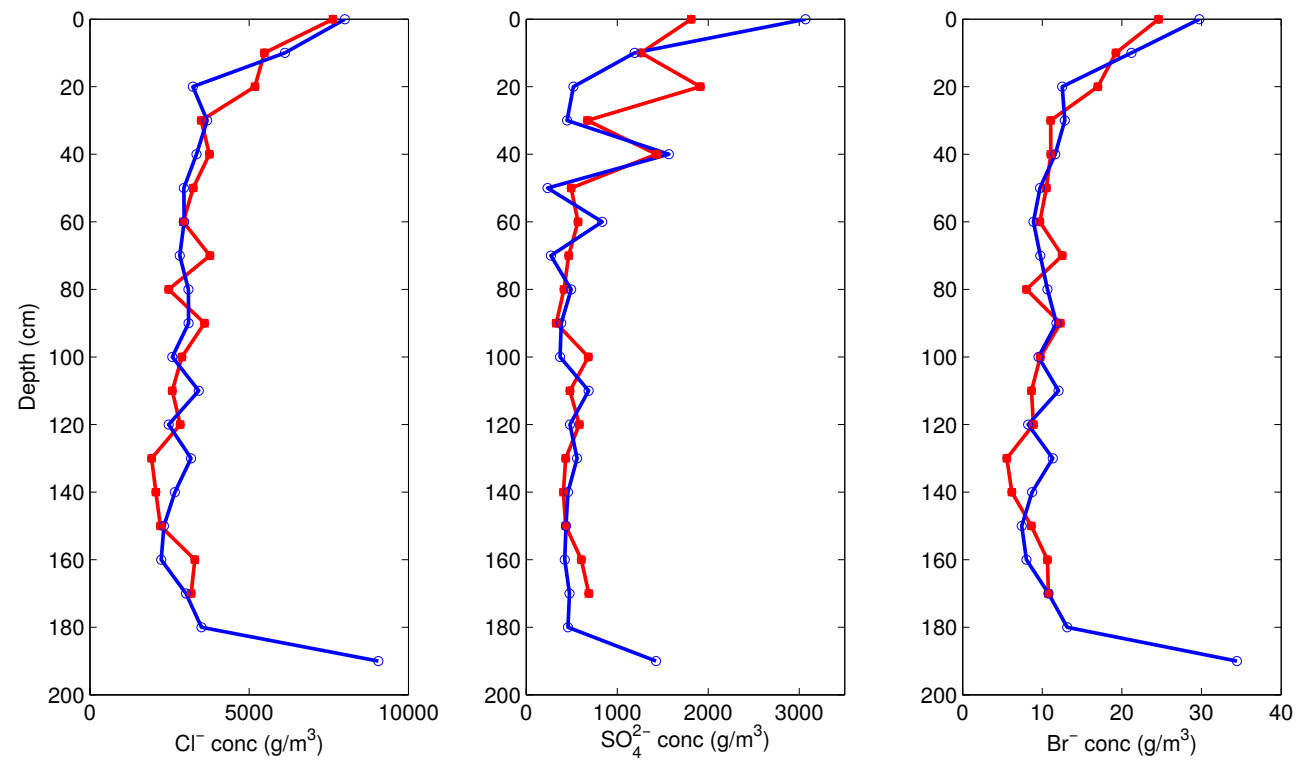

Figure 2. Anion concentrations for sea ice cores. Butter Point Site samples are shown in red filled-in squares and red lines, while Iceberg Site samples are shown in blue open circles and blue lines.

\section{Results}

Raw anion concentrations for sea ice, surface snow, and blowing snow samples are provided in the Supplement. Sea ice anion concentrations had nearly identical profiles for Butter Point and Iceberg cores, with both showing the expected C-shape profile (see Fig. 2) (Eicken, 1992). Note that the deepest sample for Iceberg Site was directly at the base of the core, while the deepest sample for Butter Point was $8 \mathrm{~cm}$ above the base, due to a mushy, poorly defined basal layer, and thus missed the saltiest portion. Chloride concentrations ranged from $2000-8000 \mathrm{~g} \mathrm{~m}^{-3}$, while bromide concentrations ranged from $5-35 \mathrm{~g} \mathrm{~m}^{-3}$. Sulfate concentrations ranged from $2-3000 \mathrm{~g} \mathrm{~m}^{-3}$, with increased variation observed over the top $40 \mathrm{~cm}$ of both cores. Nitrate concentrations were below detection limits for all sea ice core samples.

Surface snow anion concentrations varied greatly, but were of similar magnitude at the two sites and showed no noticeable trend with time over the field campaign. Concentrations ranged from $200-5000 \mathrm{~g} \mathrm{~m}^{-3}$ chloride, $1.0-16 \mathrm{~g} \mathrm{~m}^{-3}$ bromide, $20-2300 \mathrm{~g} \mathrm{~m}^{-3}$ sulfate, and $0-1.2 \mathrm{~g} \mathrm{~m}^{-3}$ nitrate, though the majority of samples were below detection limits in nitrate. If we assume $\mathrm{Cl}$ concentrations to be a good proxy to estimate salinity using sea water ion ratios, this corresponds to a mean surface snow salinity of 3 PSU, with a range of 0.4-9 PSU. There was little snow cover at Butter Point with the surface varying from completely wind scoured to several $\mathrm{cm}$ of snow. Iceberg Site had a more variable snowpack, with prevalent rafted ice and sastrugi, resulting in snow depths varying from tens of $\mathrm{cm}$ to over $1 \mathrm{~m}$. A $21 \mathrm{~cm}$ snow pit was dug $15 \mathrm{~km}$ from Butter Point Site to study a more consistent snowpack that is representative of the greater first-year sea ice of the region. In this snow pit, both chloride and bromide concentrations increased steadily from the snow surface to the snow/ice interface, with concentrations ranging from $500-1600 \mathrm{~g} \mathrm{~m}^{-3}$ chloride and $1.5-6 \mathrm{~g} \mathrm{~m}^{-3}$ bromide. Sulfate concentrations ranged from $30-50 \mathrm{~g} \mathrm{~m}^{-3}$, but showed a Cshaped profile with highest concentrations found near the top and bottom of the snow pit. A second snow pit located slightly closer to the open ocean showed similar trends.

Anion concentrations from the blowing snow samples collected on 25 October in both towers varied greatly, including separate samples from the same collection baskets, indicating that blown snow can be quite varied in its salt concentration. Concentrations ranged from $50-6800 \mathrm{~g} \mathrm{~m}^{-3}$ chloride, 0.2 $18.5 \mathrm{~g} \mathrm{~m}^{-3}$ bromide, $3-240 \mathrm{~g} \mathrm{~m}^{-3}$ sulfate, and $0.4-23 \mathrm{~g} \mathrm{~m}^{-3}$ nitrate. Using chloride concentrations to derive an estimate of salinity, blowing snow samples ranged from 0.1 to $12 \mathrm{PSU}$. Comparing the 0.3 and $5.5 \mathrm{~m}$ baskets at both sites suggests a 10-fold increase in salinity from 0.6 to 6 PSU. However, when all blowing snow samples are considered, there is not a statistically significant trend of increasing salt concentration with basket height, except for nitrate where concentrations increased with height above the snow surface.

Anion concentrations can provide a general understanding of the overall salinity of the snow and ice, but in order to understand chemical reaction activity, it is instructive to calculate anion concentration ratios. The $\mathrm{Br}^{-} / \mathrm{Cl}^{-}$mass ratio has long been used as a metric for analyzing both frozen and liquid saline water samples, and comparing measured values to the well established 1:290 ratio observed in seawater (Morris and Riley, 1966). This ratio is plotted in Fig. 3 for all samples at both sites. $\mathrm{Br}^{-} / \mathrm{Cl}^{-}$mass ratios were relatively constant for all sea ice samples $(1: 281 \pm 24)$ and all surface 


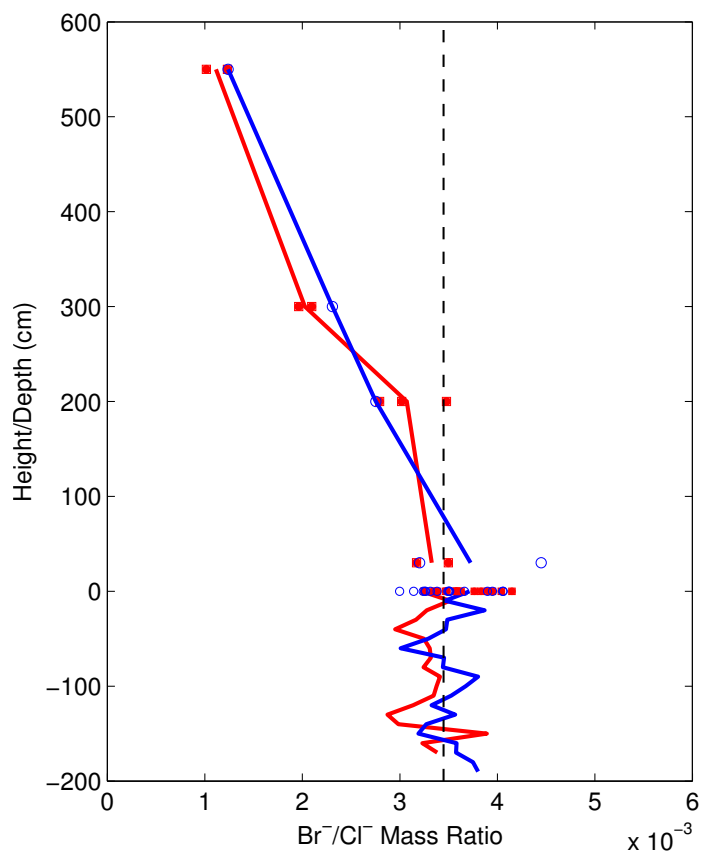

Figure 3. $\mathrm{Br}^{-} / \mathrm{Cl}^{-}$mass ratios for sea ice (negative heights), surface snow (height of 0 ), and blowing snow (height above snow surface). Blowing snow lines connect averages for each basket height. Butter Point Site samples are shown in red filled-in squares and red lines, while Iceberg Site samples are shown in blue open circles and blue lines. The standard ocean $\mathrm{Br}^{-} / \mathrm{Cl}^{-}$mass ratio is shown as a black dashed line (Morris and Riley, 1966).

snow samples $(1: 296 \pm 22)$. However, there was a linear correlation between $\mathrm{Br}^{-} / \mathrm{Cl}^{-}$mass ratios for blowing snow relative to height at both Butter Point $\left(r^{2}=0.89\right)$ and Iceberg Site $\left(r^{2}=0.93\right)$. Sulfate mass ratios in sea ice, surface snow, and blowing snow did not show as clear a trend (Fig. 4). In sea ice, the $\mathrm{SO}_{4}^{2-} / \mathrm{Cl}^{-}$mass ratio was roughly $1: 7$ in the bottom half of the cores, consistent with what is generally observed in seawater (Morris and Riley, 1966), but varied from approximately $1: 2$ to $1: 12$ in the upper halves of the cores. Surface snow mass ratios also were quite variable ranging from $1: 1$ to $1: 19$ with no clear correlations. Collected lofted snow was quite depleted in sulfate with mass ratios reaching $1: 20$ to $1: 40$, but did not show the linear trend with height observed with bromide.

\section{Discussion}

Observation of bromide depletion relative to other salts is an indication of heterogeneous atmospheric chemical reactions and bromine activation (Adams et al., 2002; Huff and Abbatt, 2002; Simpson et al., 2005). Although there was some variability in $\mathrm{Br}^{-} / \mathrm{Cl}^{-}$mass ratios for sea ice and surface snow, these ratios were remarkably constant, just over $1: 300$. As shown in Fig. 3, signs of bromide depletion occur above the snowpack, with greater depletion occurring at greater

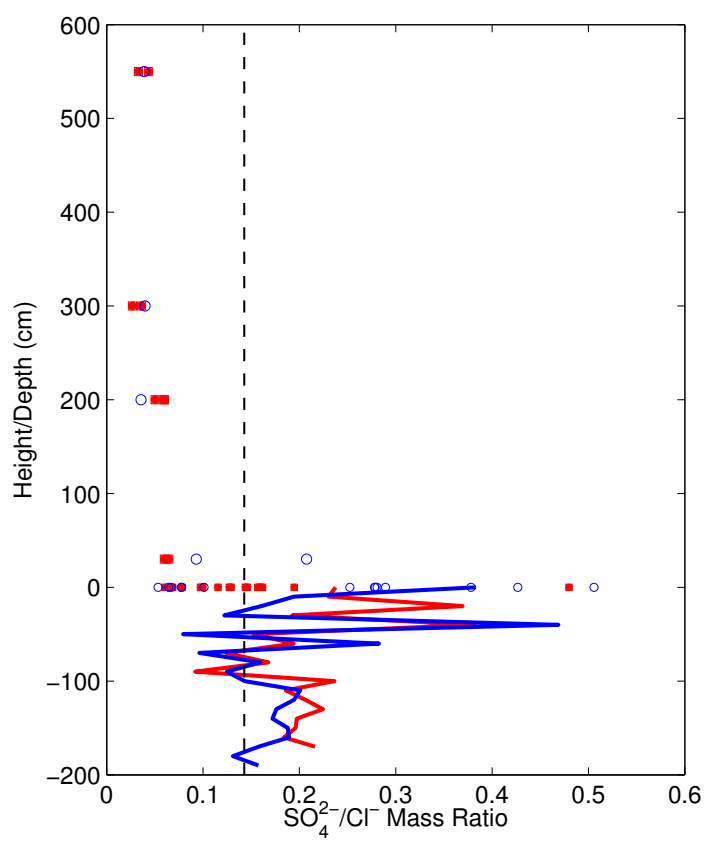

Figure 4. $\mathrm{SO}_{4}^{2-} / \mathrm{Cl}^{-}$mass ratios for sea ice (negative heights), surface snow (height of 0 ), and blowing snow (height above snow surface). Butter Point Site samples are shown in red filled-in squares (snow samples) and a red line (sea ice), while Iceberg Site samples are shown in blue open circles (snow samples) and a blue line (sea ice). The standard ocean $\mathrm{SO}_{4}^{2-} / \mathrm{Cl}^{-}$mass ratio is shown as a black dashed line (Morris and Riley, 1966).

heights, reaching mass ratios of nearly $1: 1000$ at heights of $5.5 \mathrm{~m}$. This is consistent with aerosol observations by Duce and Woodcock (1971) that measured increased bromide depletion with height, albeit at tropical latitudes. They noted a strong particle size dependence with increased bromide depletion corresponding to mid-sized aerosol particles. Further studies have shown that particle size influences the mode of transport and it may not be realistic to differentiate snow saltation and suspension based solely on wind speed and height (Nemoto and Nishimura, 2004). Nevertheless, both processes greatly increase the snow surface area exposed for gas-phase reactions by as much as 3000 times that of surface snow (Pomeroy and Brun, 2001). It is noted that snow blowing at the windspeed will have no relative motion compared to the gases and gas-phase diffusion becomes an important consideration, especially for large grain particles. Local turbulence however, will help to overcome some of these diffusion limitations (Nemoto and Nishimura, 2004). We also note that sublimation of blowing snow particles likely has a strong effect on anion concentrations. Consistent with the mechanism suggested by Yang et al. (2008), lighter particles would remain airborne for longer periods of time, leading to suspension at greater heights and more time for photochemical reactions. However, since particle sizes were not measured in 
this study, we solely mention the potential sublimation may have on increasing bromine release through this pathway.

A depletion factor (DF) was defined such that $\mathrm{DF}=0$ signifies no bromine depletion in particles, and $\mathrm{DF}=1$ signifies complete depletion (Yang et al., 2005). We note that a negative value for DF indicates bromine enrichment. Averaging the $\mathrm{Br}^{-} / \mathrm{Cl}^{-}$mass ratios at each height for Butter Point yields $\mathrm{DF}=0.04,0.11,0.41$, and 0.68 for heights of $0.3,2.0$, 3.0 , and $5.5 \mathrm{~m}$, respectively. At Iceberg Site, $\mathrm{DF}=-0.08$, $0.20,0.33$, and 0.64 for the four heights, respectively. Depletion factors were relatively small for both surface snow and ice core samples, with values ranging from -0.20 to 0.13 and -0.13 to 0.17 , respectively. These values are consistent with previously reported values and currently used in some models (Sander et al., 2003; Yang et al., 2005). Previously, Simpson et al. (2005) observed up to $90 \%$ bromide depletion in surface snow, while Jacobi et al. (2012) observed up to $70 \%$ depletion in snow mobilized $5 \mathrm{~cm}$ above the surface. The latter study also noted that during a blowing snow event, there was first bromide enrichment in the snow during the initial part of the storm followed by later bromide depletion (Jacobi et al., 2012). An increased depletion factor can either signify bromide depletion due to bromine release or chloride enrichment from, for example, gaseous HCL uptake. If the latter hypothesis were true, one would expect to observe increased chloride concentrations in higher baskets. The lack of an observed chloride trend with height leads to our interpretation that the decreased mass ratio is a clear indicator of bromine activation. Interestingly, lower $\mathrm{Br}^{-} / \mathrm{Cl}^{-}$ratios have also been found to correspond with a decrease in chlorine release (Wren et al., 2013). This is due to the fact that $\mathrm{BrCl}$ plays a critical role in chlorine production. $\mathrm{BrCl}$ is initially formed from the reaction between $\mathrm{HOBr}$ and $\mathrm{Cl}^{-}$, and then upon later photolysis, can lead to chlorine release (Wren et al., 2013).

Previously, bromine activation and ODEs were observed in both low $\left(<5 \mathrm{~m} \mathrm{~s}^{-1}\right)$ and high $\left(>12 \mathrm{~m} \mathrm{~s}^{-1}\right)$ winds (Jones et al., 2009). Here, the blowing snow event occurred during moderate winds of approximately $10 \mathrm{~m} \mathrm{~s}^{-1}$. Since the wind was from the south and there was no new precipitation, it is safe to assume that the snow originated from the surface of first-year sea ice. It is noted that the blowing snow event lasted approximately $4-6 \mathrm{~h}$, and that snow samples from the baskets were not collected until 10-12 h later. During this time, wind speeds dropped to less than $5 \mathrm{~m} \mathrm{~s}^{-1}$, and it is possible that the collected snow was exposed to further wind scouring. However, all baskets would have experienced a similar degree of scouring in these minimal winds and the effect would be minor over the short time period prior to collection. Further, the collected snow was mostly windpacked, suggesting it was unlikely the wind penetrated both the $150 \mu \mathrm{m}$ nylon monofilament mesh of the basket and the interior bulk of the snow. Future studies, however, may attempt to better seal off collected blown snow.
The surface snow $\mathrm{Br}^{-} / \mathrm{Cl}^{-}$mass ratios at both sites showed little variation and no observed trend with date or meteorology over the month-long campaign. If there was a significant amount of lofted snow being depleted in bromide and then falling back to the snow surface, one might expect to detect a signal in the surface snow chemistry. The lack of recorded bromide depletion in the surface snow may indicate that either surface snow bromide concentration is quickly replenished or that blowing snow represents only a small portion of the surface snowpack. Surface snow will be replenished in bromide through interaction with saline brine (Oldridge and Abbatt, 2011), deposition of $\mathrm{HOBr}$ as a byproduct of the reaction between $\mathrm{BrO}$ and $\mathrm{HO}_{2}$, deposition of $\mathrm{HBr}$, and deposition of aerosol-phase bromine. In cold ambient environments, frost flowers, surface snow, and the sea ice surface have been shown to be bromide enriched sources, likely due to the precipitation of $\mathrm{NaCl}$ (Kalnajs and Avallone, 2006; Morin et al., 2008). Additionally, recycling of deposited bromine plays a critical role with as much as $75 \%$ of deposited bromine being re-emitted into the gas phase as $\mathrm{Br}_{2}$ or $\mathrm{BrCl}$ (Piot and von Glasow, 2008). In future work, it would be informative to collect both surface and blowing snow during stronger wind events.

The sulfate depletion observed in lofted snow is consistent with the observations of others, most likely a product of mirabilite precipitation occurring at temperatures below $-8^{\circ} \mathrm{C}$ (Rankin et al., 2000). The range of $\mathrm{SO}_{4}^{2-} / \mathrm{Cl}^{-}$mass ratios measured in surface snow and the upper halves of the ice cores is also likely due to similar interactions. Sulfate depletion can result from a wide variety of processes involving brine and mirabilite formation as brine constantly moves through sea ice and is also wicked up by surface snow (Krnavek et al., 2012). In addition, non-sea salt sourced sulfate may provide additional sulfate to the surface snowpack (Rankin and Wolff, 2003; Krnavek et al., 2012).

Nitrate concentration in seawater is highly dependent upon phytoplankton blooms, and therefore varies greatly from single digit $\mathrm{g} \mathrm{m}^{-3}$ to less than one $\mathrm{g} \mathrm{m}^{-3}$ (e.g., Gordon et al., 2000; Arrigo et al., 1997). Thus, it was not surprising that sea ice samples were below the quantification limit for nitrate. Surface snow samples also were generally below nitrate detection limits, and those with quantifiable concentrations showed no noticeable trend. Nitrate snow photochemistry is quite complex, with many processes both adding and subtracting nitrate from the snowpack (Grannas et al., 2007; Krnavek et al., 2012). Nitrate sources include biomass burning, lightning production, soil exhalation, and anthropogenic pollutants that can be carried long distances through atmospheric transport (Galloway et al., 2004; Krnavek et al., 2012). The increase in nitrate concentration observed with basket height may be attributed to increased atmospheric interactions higher above the snowpack. Additionally, basket nitrate concentration may also be influenced by interactions occurring while the snow was sitting in the basket but prior to collection, as cycling of different nitrogen-containing com- 
pounds is relatively fast and can vary greatly during a day (Grannas et al., 2007). Considering the number of competing reactions, more data points would be needed to make conclusive statements regarding the cycling of nitrate in the polar boundary layer.

\section{Conclusions}

In summary, this work examined the mass ratio of $\mathrm{Br}^{-} / \mathrm{Cl}^{-}$ in blowing snow during mid-strength winds to better understand mechanisms leading to bromine activation. It was found that while $\mathrm{Br}^{-} / \mathrm{Cl}^{-}$mass ratios remained relatively constant for sea ice and surface snow, bromide becomes strongly depleted relative to chloride in lofted snow. Thus, we conclude the blowing snow particles provide a very viable surface for the initial heterogeneous reactions initializing ODEs to occur. The findings of this study are consistent with previous modeling results (Yang et al., 2010), suggesting that blowing snow has the capacity to explain the occurrence of ODEs in the polar springtime.

\section{The Supplement related to this article is available online at doi:10.5194/acp-15-7537-2015-supplement.}

Acknowledgements. This research was supported by a National Science Foundation (NSF) Grant \# 1043145. The authors would like to thank Anthony Faia, Josh Landis, Dave Ferris, Howard Roscoe, and the two referees for guidance with IC and insightful suggestions in preparing this manuscript.

All data is available online at http://engineering.dartmouth.edu/ materials/bromide/data.html.

Edited by: R. Sander

\section{References}

Abbatt, J. P. D., Thomas, J. L., Abrahamsson, K., Boxe, C., Granfors, A., Jones, A. E., King, M. D., Saiz-Lopez, A., Shepson, P. B., Sodeau, J., Toohey, D. W., Toubin, C., von Glasow, R., Wren, S. N., and Yang, X.: Halogen activation via interactions with environmental ice and snow in the polar lower troposphere and other regions, Atmos. Chem. Phys., 12, 6237-6271, doi:10.5194/acp-12-6237-2012, 2012.

Adams, J. W., Holmes, N. S., and Crowley, J. N.: Uptake and reaction of $\mathrm{HOBr}$ on frozen and dry $\mathrm{NaCl} / \mathrm{NaBr}$ surfaces between 253 and 233 K, Atmos. Chem. Phys., 2, 79-91, doi:10.5194/acp2-79-2002, 2002.

Albert, M. R., Grannas, A. M., Bottenheim, J., Shepson, P. B., and Perron, F. E.: Processes and Properties of Snow-Air Transfer in the High Arctic with Application to Interstitial Ozone at Alert, Canada, Atmos. Environ., 36, 2779-2787, 2002.
Arrigo, K. R., Worthen, D. L., Lizotte, M. P., Dixon, P., and Dieckmann, G.: Primary Production in Antarctic Sea Ice, Science, 276, 394-397, doi:10.1126/science.276.5311.394, 1997.

Barrie, L. A., Bottenheim, J. W., Schnell, R. C., Crutzen, P. J., and Rasmussen, R. A.: Ozone Destruction and PhotochemicalReactions at Polar Sunrise in the Lower Arctic Atmosphere, Nature, 334, 138-141, 1988.

Domine, F., Sparapani, R., Ianniello, A., and Beine, H. J.: The origin of sea salt in snow on Arctic sea ice and in coastal regions, Atmos. Chem. Phys., 4, 2259-2271, doi:10.5194/acp-4-2259-2004, 2004.

Domine, F., Taillandier, A. S., Simpson, W. R., and Severin, K.: Specific Surface Area, Density and Microstructure of Frost Flowers, Geophys. Res. Lett., 32, L13502, doi:10.1029/2005GL023245, 2005

Duce, R. A. and Woodcock, A. H.: Difference in Chemical Composition of Atmospheric Sea Salt Particles Produced in the Surf Zone and on the Open Sea in Hawaii, Tellus, 23, 427-435, 1971.

Eicken, H.: Salinity Profiles of Antarctic Sea Ice: Field Data and Model Results, J. Geophys. Res., 97, 15545-15557, 1992.

Fan, S.-M. and Jacob, D. J.: Surface Ozone Depletion in Arctic Spring Sustained by Bromine Reacions on Aerosols, Nature, 359, 522-524, 1992.

Frieß, U., Hollwedel, J., Konig-Langlo, G., Wagner, T., and Platt, U.: Dynamics and Chemistry of Tropospheric Bromine Explosion Events in the Antarctic Coastal Region, J. Geophys. Res., 109, D06305, doi:10.1029/2003JD004133, 2004.

Frieß, U., Sihler, H., Sander, R., Pohler, D., Yilmaz, S., and Platt, U.: The Vertical Distribution of $\mathrm{BrO}$ and Aerosols in the Arctic: Measurements by Active and Passive Differential Optical Absorption Spectroscopy, J. Geophys. Res., 116, D00R04, doi:10.1029/2011JD015938, 2011.

Galloway, J. N., Dentener, F. J., Capone, D. G., Boyer, E. W., Howarth, R. W., Seitzinger, S. P., Asner, G. P., Cleveland, C. C., Green, P. A., Holland, E. A., Karl, D. M., Michaels, A. F., Porter, J. H., Townsend, A. R., and Vorosmarty, C. J.: Nitrogen Cycles: Past, Present, and Future, Biogeochemistry, 70, 153-226, doi:10.1007/s10533-004-0370-0, 2004.

Gordon, L. I., Codispoti, L. A., Jennings Jr., J. C., Millero, F. J., Morrison, J. M., and Sweeney, C.: Seasonal Evolution of Hydrographic Properties in the Ross Sea, Antarctica, 1996-1997, Deep-Sea Res. Pt. II, 47, 3095-3117, 2000.

Grannas, A. M., Jones, A. E., Dibb, J., Ammann, M., Anastasio, C., Beine, H. J., Bergin, M., Bottenheim, J., Boxe, C. S., Carver, G., Chen, G., Crawford, J. H., Dominé, F., Frey, M. M., Guzmán, M. I., Heard, D. E., Helmig, D., Hoffmann, M. R., Honrath, R. E., Huey, L. G., Hutterli, M., Jacobi, H. W., Klán, P., Lefer, B., McConnell, J., Plane, J., Sander, R., Savarino, J., Shepson, P. B., Simpson, W. R., Sodeau, J. R., von Glasow, R., Weller, R., Wolff, E. W., and Zhu, T.: An overview of snow photochemistry: evidence, mechanisms and impacts, Atmos. Chem. Phys., 7, 43294373, doi:10.5194/acp-7-4329-2007, 2007.

Halfacre, J. W., Knepp, T. N., Shepson, P. B., Thompson, C. R., Pratt, K. A., Li, B., Peterson, P. K., Walsh, S. J., Simpson, W. R., Matrai, P. A., Bottenheim, J. W., Netcheva, S., Perovich, D. K., and Richter, A.: Temporal and spatial characteristics of ozone depletion events from measurements in the Arctic, Atmos. Chem. Phys., 14, 4875-4894, doi:10.5194/acp-14-4875-2014, 2014. 
Helmig, D., Boylan, P., Johnson, B., Oltmans, S., Fairall, C., Staebler, R., Weinheimer, A., Orlando, J., Knapp, D. J., Montzka, D. D., Flocke, F., Frieß, U., Sihler, H., and Shepson, P. B.: Ozone Dynamics and Snow-Atmosphere Exchanges During Ozone Depletion Events at Barrow, Alaska, J. Geophys. Res., 117, D20303, doi:10.1029/2012JD017531, 2012.

Huff, A. K. and Abbatt, J. P. D.: Kinetics and Product Yields in the Heterogeneous Reactions of $\mathrm{HOBr}$ with Simulated Sea-Ice Surfaces, J. Phys. Chem. A., 106, 5279-5287, 2002.

Jacobi, H. W., Voisin, D., Jaffrezo, J. L., Cozic, J., and Douglas, T. A.: Chemical Composition of the Snowpack During the OASIS Spring Campaign 2009 at Barrow, Alaska, J. Geophys. Res., 117, D00R13, doi:10.1029/2011JD016654, 2012.

Jones, A. E., Anderson, P. S., Begoin, M., Brough, N., Hutterli, M. A., Marshall, G. J., Richter, A., Roscoe, H. K., and Wolff, E. W.: $\mathrm{BrO}$, blizzards, and drivers of polar tropospheric ozone depletion events, Atmos. Chem. Phys., 9, 4639-4652, doi:10.5194/acp-94639-2009, 2009.

Jones, A. E., Anderson, P. S., Wolff, E. W., Roscoe, H. K., Marshall, G. J., Richter, A., Brough, N., and Colwell, S. R.: Vertical structure of Antarctic tropospheric ozone depletion events: characteristics and broader implications, Atmos. Chem. Phys., 10, 7775-7794, doi:10.5194/acp-10-7775-2010, 2010.

Kaleschke, L., Richter, A., Burrows, J., Afe, O., Heygster, G., Notholt, J., Rankin, A. M., Roscoe, H. K., Hollwedel, J., Wagner, T., and Jacobi, H.-W.: Frost Flowers on Sea Ice as a Source of Sea Salt and Their Influence on Tropospheric Halogen Chemistry, Geophys. Res. Lett., 31, L16114, doi:10.1029/2004GL020655, 2004.

Kalnajs, L. E. and Avallone, L. M.: Frost Flower Influence on Springtime Boundary-Layer Ozone Depletion Events and Atmospheric Bromine Levels, Geophys. Res. Lett., 33, L10810, doi:10.1029/2006GL025809, 2006.

Kreher, K., Johnston, P. V., Wood, S. W., Nardi, B., and Platt, U.: Ground-Based Measurements of Tropospheric and Stratospheric $\mathrm{BrO}$ at Arrival Heights, Antarctica, Geophys. Res. Lett., 24, 3021-3024, 1997.

Krnavek, L., Simpson, W. R., Carlson, D., Domine, F., Douglas, T. A., and Sturm, M.: The Chemical Composition of Surface Snow in the Arctic: Examining Marine, Terrestrial, and Atmospheric Influences, Atmos. Environ., 50, 349-359, 2012.

Liao, J., Huey, L. G., Tanner, D. J., Flocke, F. M., Orlando, J. J., Neuman, J. A., Nowak, J. B., Weinheimer, A. J., Hall, S. R., Smith, J. N., Fried, A., Staebler, R. M., Wang, Y., Koo, J.-H., Cantrell, C. A., Weibring, P., Walega, J., Knapp, D. J., Shepson, P. B., and Stephens, C. R.: Observations of Inorganic Bromine ( $\mathrm{HOBr}, \mathrm{BrO}$, and $\left.\mathrm{Br}_{2}\right)$ Speciation at Barrow, Alaska, in Spring 2009, J. Geophys. Res., 117, D00R16, doi:10.1029/2011JD016641, 2012.

Light, B., Maykut, G. A., and Grenfell, T. C.: Effects of Temperature on the Microstructure of First-Year Arctic Sea Ice, J. Geophs. Res., 108, 3051, doi:10.1029/2001JC000887, 2003.

Massom, R. A., Eicken, H., Haas, C., Jeffries, M. O., Drinkwater, M. R., Sturm, M., Worby, A. P., Wu, X., Lytle, V. I., Ushio, S., Morris, K., Reid, P. A., and Allison, S. G. W. I.: Snow on Antarctic Sea Ice, Rev. Geophys., 39, 413-445, 2001.

McConnell, J. C., Henderson, G. S., Barrie, L. A., Bottenheim, J. W., Niki, H., Langford, C. H., and Templeton, E. M. J.: Photochemical Bromine Production Implicated in Arc- tic Boundary-Layer Oone Depletion, Nature, 355, 150-152, doi:10.1038/355150a0, 1992.

Morin, S., Marion, G. M., von Glasow, R., Voisin, D., Bouchez, J., and Savarino, J.: Precipitation of salts in freezing seawater and ozone depletion events: a status report, Atmos. Chem. Phys., 8, 7317-7324, doi:10.5194/acp-8-7317-2008, 2008.

Morris, A. W. and Riley, J. P.: The bromide/chlorinity and sulphate/chlorinity ratio in sea water, Deep-Sea Res., 13, 699-705, doi:10.1016/0011-7471(66)90601-2, 1966.

Nemoto, M. and Nishimura, K.: Numerical Simulation of Snow Saltation and Suspension in a Turbulent Boundary Layer, J. Geophys. Res., 109, D18206, doi:10.1029/2004JD004657, 2004.

Obbard, R. W., Roscoe, H. K., Wolff, E. W., and Atkinson, H. M.: Frost Flower Surface Area and Chemistry as a Function of Salinity and Temperature, J. Geophys. Res., 114, D20305, doi:10.1029/2009JD012481, 2009.

Oldridge, N. W. and Abbatt, J. P. D.: Formation of Gas-Phase Bromine from Interaction of Ozone with Frozen and Liquid $\mathrm{NaCl} / \mathrm{Br}$ Solutions: Quantitative Separation of Surficial Chemistry from Bulk-Phase Reaction, J. Phys. Chem. A, 115, 25902598, doi:10.1021/jp200074u, 2011.

Perovich, D. K. and Richter-Menge, J. A.: Surface Characteristics of Lead Ice, J. Geophys. Res., 99, 16341-16350, 1994.

Piot, M. and von Glasow, R.: The potential importance of frost flowers, recycling on snow, and open leads for ozone depletion events, Atmos. Chem. Phys., 8, 2437-2467, doi:10.5194/acp-82437-2008, 2008.

Pomeroy, J. W. and Brun, E.: Physical Properties of Snow, in: Snow Ecology: An Interdisciplinary Examination of Snow-Covered Ecosystems, edited by: Jones, H. G., Pomeroy, J. W., Walker, D. A., and Hoham, R. W., 45-126, Cambridge University Press, Cambridge, UK, 2001.

Pratt, K. A., Custard, K. D., Shepson, P. B., Douglas, T. A., Pohler, D., General, S., Zielcke, J., Simpson, W. R., Platt, U., Tanner, D. J., Huey, L. G., Carlsen, M., and Stirm, B. H.: Photochemical Production of Molecular Bromine in Arctic Surface Snowpacks, Nat. Geosci., 6, 351-356, doi:10.1038/NGEO1779, 2013.

Rankin, A. M. and Wolff, E. W.: A Year-Long Record of SizeSegregated Aerosol Composition at Halley, Antarctica, J. Geophys. Res., 108, 4775, doi:10.1029/2003JD003993, 2003.

Rankin, A. M., Auld, V., and Wolff, E. W.: Frost Flowers as a Source of Fractionated Sea Salt Aerosol in the Polar Regions, Geophys. Res. Lett., 27, 3469-3472, 2000.

Rankin, A. M., Wolff, E. W., and Martin, S.: Frost Flowers: Implications for Tropospheric Chemistry and Ice Core Interpretation, J. Geophys. Res., 107, 4683, doi:10.1029/2002JD002492, 2002.

Roscoe, H. K., Brooks, B., Jackson, A. V., Smith, M. H., Walker, S. J., Obbard, R. W., and Wolff, E. W.: Frost Flowers in the Laboratory: Growth, Characteristics, Aerosol, and the Underlying Sea Ice, J. Geophys. Res., 116, D12301, doi:10.1029/2010JD015144, 2011.

Sander, R., Keene, W. C., Pszenny, A. A. P., Arimoto, R., Ayers, G. P., Baboukas, E., Cainey, J. M., Crutzen, P. J., Duce, R. A., Hönninger, G., Huebert, B. J., Maenhaut, W., Mihalopoulos, N., Turekian, V. C., and Van Dingenen, R.: Inorganic bromine in the marine boundary layer: a critical review, Atmos. Chem. Phys., 3, 1301-1336, doi:10.5194/acp-3-1301-2003, 2003.

Simpson, W. R., Alvarez-Alviles, L., Douglas, T. A., Sturm, M., and Domine, F.: Halogens in the Coastal Snow Pack Near Bar- 
row, Alaska: Evidence for Active Bromine Air-Snow Chemistry During Springtime, Geophys. Res. Lett., 32, L04811, doi:10.1029/2004GL021748, 2005.

Simpson, W. R., Carlson, D., Hönninger, G., Douglas, T. A., Sturm, M., Perovich, D., and Platt, U.: First-year sea-ice contact predicts bromine monoxide $(\mathrm{BrO})$ levels at Barrow, Alaska better than potential frost flower contact, Atmos. Chem. Phys., 7, 621-627, doi:10.5194/acp-7-621-2007, 2007a.

Simpson, W. R., von Glasow, R., Riedel, K., Anderson, P., Ariya, P., Bottenheim, J., Burrows, J., Carpenter, L. J., Frieß, U., Goodsite, M. E., Heard, D., Hutterli, M., Jacobi, H.-W., Kaleschke, L., Neff, B., Plane, J., Platt, U., Richter, A., Roscoe, H., Sander, R., Shepson, P., Sodeau, J., Steffen, A., Wagner, T., and Wolff, E.: Halogens and their role in polar boundary-layer ozone depletion, Atmos. Chem. Phys., 7, 4375-4418, doi:10.5194/acp-74375-2007, 2007b.

Thomas, D. N. and Dieckmann, G. S.: Sea Ice, Wiley-Blackwell, Hoboken, NJ, USA, 2009.

Toyota, K., McConnell, J. C., Lupu, A., Neary, L., McLinden, C. A., Richter, A., Kwok, R., Semeniuk, K., Kaminski, J. W., Gong, S.-L., Jarosz, J., Chipperfield, M. P., and Sioris, C. E.: Analysis of reactive bromine production and ozone depletion in the Arctic boundary layer using 3-D simulations with GEM-AQ: inference from synoptic-scale patterns, Atmos. Chem. Phys., 11, 3949-3979, doi:10.5194/acp-11-3949-2011, 2011.
Vogt, R., Crutzen, P. J., and Sander, R.: A Mechanism for Halogen Release From Sea-Salt Aerosol in the Remote Marine Boundary Layer, Nature, 383, 327-330, 1996.

Wagenbach, D., Ducroz, F., Mulvaney, R., Keck, L., Minikin, A., Legrand, M., Hall, J. S., and Wolff, E. W.: Sea-Salt Aerosol in Coastal Antarctic Regions, J. Geophys. Res., 103, 10961-10974, 1998.

Wessel, S., Aoki, A., Winkler, P., Weller, R., Herber, A., Gernandt, H., and Schrems, O.: Tropospheric Ozone Depltion in Polar Regions: A Comparison of Observations in the Arctic and Antarctic, Tellus B, 50, 34-50, 1998.

Wren, S. N., Donaldson, D. J., and Abbatt, J. P. D.: Photochemical chlorine and bromine activation from artificial saline snow, Atmos. Chem. Phys., 13, 9789-9800, doi:10.5194/acp-13-97892013, 2013.

Yang, X., Cox, R. A., Warwick, N. J., Pyle, J. A., Carver, G. D., O'Connor, F. M., and Savage, N. H.: Tropospheric Bromine Chemistry and its Impacts on Ozone: A Model Study, J. Geophys. Res., 110, D23311, doi:10.1029/2005JD006244, 2005.

Yang, X., Pyle, J. A., and Cox, R. A.: Sea Salt Aerosol Production and Bromine Release: Role of Snow on Sea Ice, Geophys. Res. Lett., 35, L16815, doi:10.1029/2008GL034536, 2008.

Yang, X., Pyle, J. A., Cox, R. A., Theys, N., and Van Roozendael, M.: Snow-sourced bromine and its implications for polar tropospheric ozone, Atmos. Chem. Phys., 10, 7763-7773, doi:10.5194/acp-10-7763-2010, 2010. 